\title{
TRANSMISSION CHANNEL AND EFFECTIVENESS OF DUAL MONETARY POLICY IN INDONESIA
}

\author{
Ascarya $^{1}$
}

\begin{abstract}
This paper investigates the transmission mechanism of dual monetary system from conventional and Islamic policy rates to inflation and output. We apply Granger Causality and VAR methods on monthly data of Indonesian banking, during the period of January 2003 to December 2009. The result shows that conventional policy rate is transmitted to output and inflation, while Islamic policy rate are not. In addition, the shock of conventional interest rate, credit and interbank rate give a negative and permanent impacts on inflation and output, except for SBI (Certificate of Bank Indonesia) with positive impact to inflation though negatively affect the output. On the other hand, the shock of PLS, financing and Islamic interbank PLS, as well as SBIS (Central Bank Shariah Certificate) give positive and permanent impacts on inflation and output.
\end{abstract}

Keywords: Monetary transmission mechanism, Interest rate pass through, Conventional Banking, Islamic Banking

JEL Classification: E43, E52, G21, G28

1 Researcher on PPSK - Bank Indonesia; ascarya@bi.go.id. The views on this paper are solely of the author and not necessarily represent the views of Bank Indonesia. Author thanks to anonymous referees and the editors, for their constructive discussion. 


\section{INTRODUCTION}

The central bank monetary policies intend to affect the real economic activities and the prices through transmission mechanisms. This requires sufficient understanding of the transmission mechanisms within the economy. Monetary policies can be transmitted through various channels, such as interest rates, monetary aggregates, credit, exchange rates, asset prices, and expectations (Warjiyo and Agung, 2002). Thus, a clear understanding of the transmission is the key for monetary policies to influence the direction of the real economy and prices in the future.

Since New Banking Act in 1998, Indonesia has implemented a dual banking system, where conventional and Islamic banks can operate side by side throughout Indonesia. With the implementation of Bank of Indonesia's Act in 1999, Bank of Indonesia has a dual mandate to conduct both conventional and Islamic monetary policies. Since then, the Islamic banking and finance has been growing rapidly.

In 2000, there were two Islamic banks and three Islamic business units (Unit Usaha Syariah) with 65 offices, controlling only $0.17 \%$ of total banking assets. At the end of 2010, 11 Islamic banks and 23 Islamic business units have been established with a total of 1,477 offices and 1,277 channeling office. The market share for Islamic banks reached $3.24 \%$ of the total assets, or equivalent of Rp 97.52 Trillion with $48 \%$ growth per year.

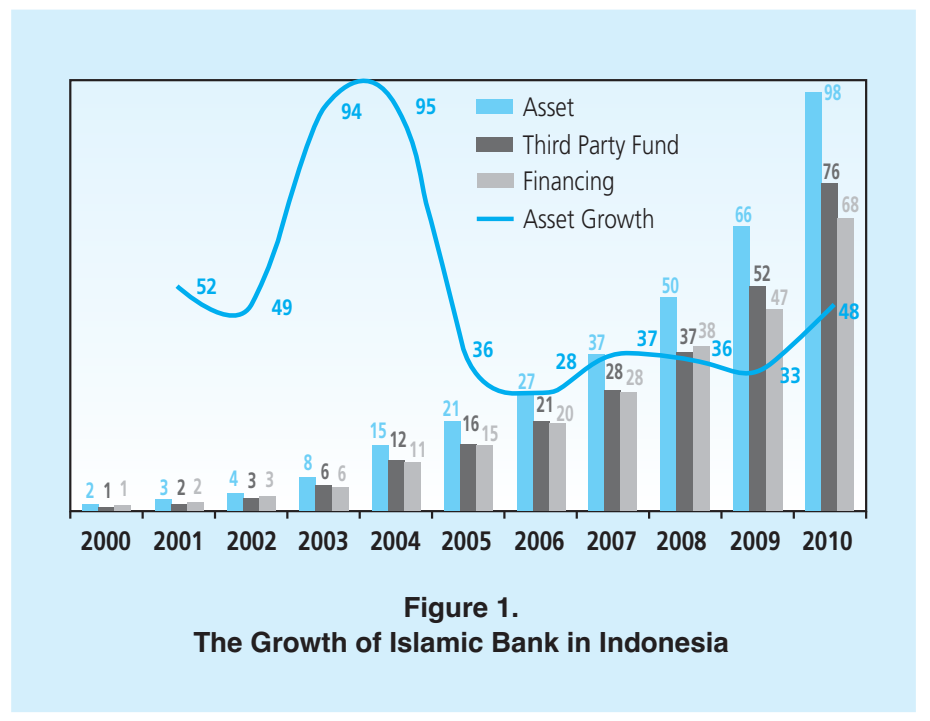

The growth of Islamic banks can be observed from the expansion of the deposit and financing. In 2000, the deposits reached a total of Rp 1.03 Trillion, and financing reached Rp 1.27 Trillion with an FDR (Financing to Deposit Ratio) of 123\%. By the end of 2010, total deposits grew by $45.47 \%$ annually, reaching Rp 76.04 Trillion, while financing grew 
by $45.42 \%$ annually, reaching $\mathrm{Rp} 68.18$ Trillion, with $89.67 \%$ FDR. This FDR level was an enormous achievement compared to Islamic banks in other countries, and also far beyond the LDR (Loan to Deposit Ratio) of conventional banks in Indonesia, which only reached $75.21 \%$.

In terms of monetary policies, Bank of Indonesia introduced the first Islamic monetary instrument in 2000, the Wadi'ah Certificate of Bank Indonesia (SWBI)2, which is still passive. Along with the rapid grow of Islamic banking; Bank Indonesia replaced SWBI with better Islamic monetary instruments in 2008, namely the Shariah Certificate of Bank Indonesia (SBIS), which is based on Ju'alah contracts ${ }^{3}$.

Since 2005, the Bank of Indonesia as the monetary authority in Indonesia has implemented full-fledged inflation targeting. This monetary policy framework is characterized with an official announcement of inflation target for a specific timeframe. In addition, the monetary policy is implemented independently to achieve high transparency and credibility. The inflation targeting framework has been implemented by most central banks, particularly in developed countries in the last seventeen years, hence the interest rate pass through has attracted more attention than before. The empirical application of the inflation targeting framework in some developed and developing countries has been proven successfully in controlling inflation at a relatively low level (See Figure 2), except for in Argentina and Indonesia.
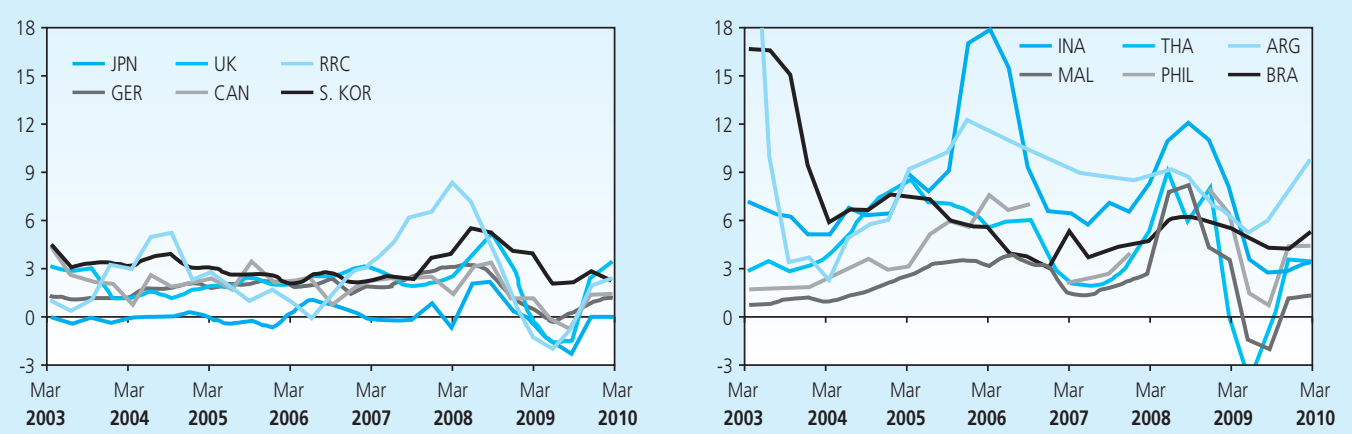

Figure 2.

Inflation on Selected Countries with Inflation Targeting Framework

However, developed countries recorded a low economic growth of around 2-3\%, while Asean countries and Latin America could achieve higher economic growth of around 4-6\%. The countries with the most prominent economic growth are China followed by Argentina.

2 Wadi'ah (deposit) is a kind of contract whereby a person leaves his valuable in the custody of others as a trust for safe keeping.

3 Ju'alah (reward for service) is a kind of contract of hiring for services, in which one party undertakes to pay a specified amount of money for rendering a defined service in accordance with the terms negotiated between them. 

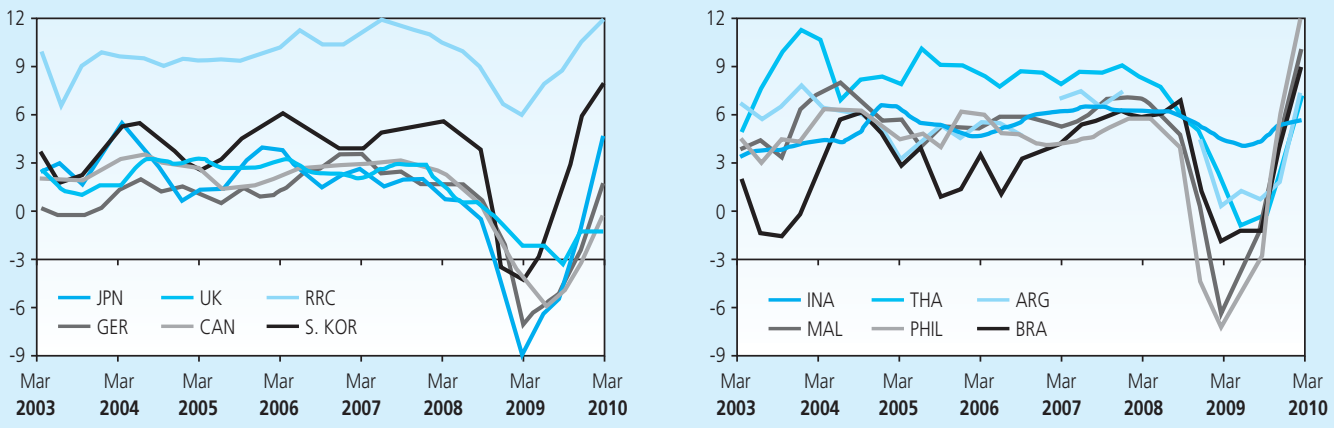

Figure 3.

The Output Growth of Countries with Inflation Targeting Framework

On the other hand, Indonesia's economic growth remains quite stable between the ranges of $4-6 \%$, including during the global financial crisis (see Figure 3.)

The interest rate pass-through illustrates the degree and the speed of market adjustment to the changes in interest rate policies set by the central bank. Interest rate pass-through is one of the prerequisites for the transmission of monetary policies to work through interest rates. Transmission channel through interest rate emphasizes the importance of price in the financial markets, towards various economic activities in real sector.

Along with the development of Islamic banking, monetary policies affect not only conventional banking but also affect Islamic banking since the transmission mechanism may also pass through Islamic banking. Multiple monetary policy instruments are not limited to interest rates only, but they also can use the profit sharing, margins or fees. Thus, in the dual monetary system, the interest rate pass-through is more appropriately termed as the 'policy rate pass-through', where the policy rate in conventional bank is interest rates, and the policy rate for Islamic banks is either profit sharing, margins, or fees.

The first aim of this paper is to identify the transmission channels of dual monetary policies in Indonesia, both through conventional banks interest rates and the Islamic banks profit sharing, margins, or fees. We also identify the relationship between the two systems and their effects towards inflation controlling. Second aim is to analyze how far the conventional bank interest rates will follow the policy rate, and how far the Islamic bank will follow the policy on profit sharing, margins or fees. We will analyze them both in short and in the long run, and compare their transmission speed. Third is to formulate an effective dual monetary policy, to increase the welfare and equalities of the society.

The second session of this paper will discuss the theoretical background and literatures, while the third session will discuss the methodology and data. The fourth session will discuss the results of the analysis, while conclusion will be presented on the last session. 


\section{THEORY}

In the last 30 years, Islamic economics and finances have been gradually implemented in various countries, alone or together with the conventional banking system. Along with the larger size and the more significant of the Islamic economics and finances, the monetary policies in Islamic perspective have also evolved.

In countries with multiple financial systems- such as Pakistan, Malaysia, and Indonesia the central bank should conduct monetary policies of both conventional and Islamic banking systems, to effectively influence the overall macroeconomic condition.

Monetary policies rest on the relationship between interest rates in the economy (which is the price of borrowing money) to the money supply to influence economic development goals, such as control of prices (inflation and exchange rates), economic growth, and the unemployment rate. This is possible because monetary authorities have the sole authority to print and to circulate the official currency of the country.

There are various types of monetary policies, and all of them try to influence the primary money (M0) by trading the debt or loan instruments of the government in open market operations. The differences among these types of monetary policy are on the instruments selected, and their target (see Table 1).

\begin{tabular}{|c|c|c|}
\hline \multicolumn{3}{|c|}{$\begin{array}{c}\text { Table } 1 . \\
\text { Types of Monetary Policy }\end{array}$} \\
\hline Monetary Regime & Instrument & Target \\
\hline Inflation Targeting & Overnight rate & Targeted inflation \\
\hline Price Level Targeting & Overnight rate & Certain targeted inflation \\
\hline Monetary Aggregates & Growth of money supply & Targeted inflation \\
\hline Fixed Exchange Rate & Spot exchange rate & Targeted exchange rate \\
\hline Gold Standard & Spot gold price & Low inflation measured with gold price \\
\hline Mixed Policy & Interest rate & Unemployment and inflation rate \\
\hline
\end{tabular}

The application of a particular monetary regime evolves over time. Gold standard regime, which sets the exchange rate of a national currency against the value of gold, was widely applied throughout the world before 1971, but no longer used after the collapse of the Bretton Woods Agreement in 1971. Price level targeting, which sets the rate of inflation each year and corrects it in the next period so that the price level does not change in the long run, was once applied in Sweden in the late 1930s. This regime was no longer implemented by any country since 2004. 
The regime of monetary aggregates of the monetarist mainstream, which is based on fixed money supply growth, was widely applied in various countries in the 1980s. In addition, the fixed exchange rate regime, which is based on fixation of the national currency value on foreign currencies, was applied by around 56 developing and small countries at different grade.

There are also mixed policy, which is based on Taylor rule and believe the interest rates will respond to the shocks of inflation and output. United States apply this since the 1980s.

The inflation targeting regime, which explicitly maintains certain level of inflation for certain period (i.e. CPI inflation), has been gaining popularity since the early 1990s and the more widely adopted by the developed and developing countries nowadays.

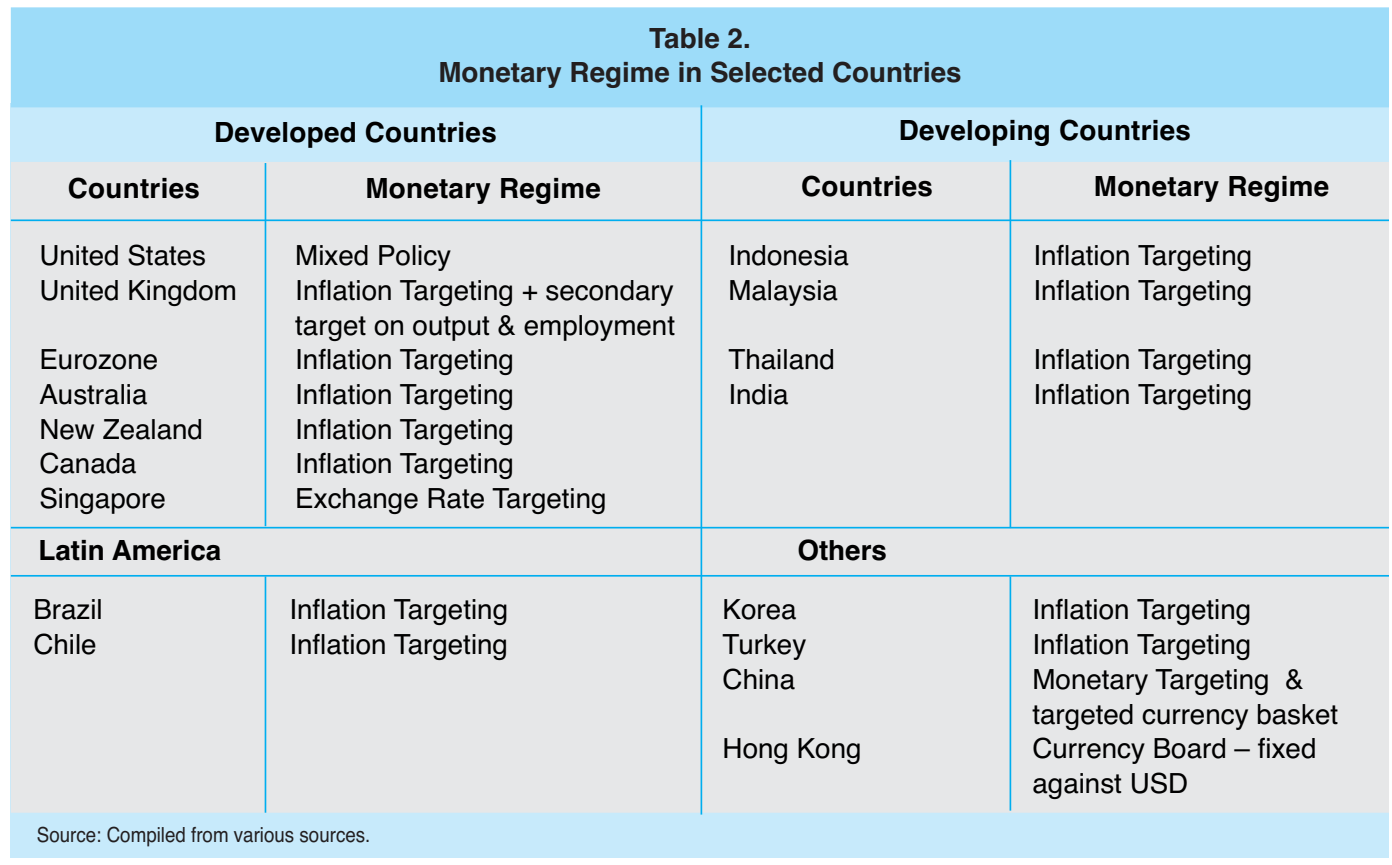

Inflation targeting is a monetary policy regime, where the central bank tries to keep inflation close to the announced target range, and is usually using the interest rate policy as the instrument. According to Alam and Masyhuri (2000), inflation targeting is primarily a framework in monetary policies that seeks to eliminate the inflation bias of discretionary monetary policy, in a transparent inflation targeting framework. Naturally, inflation targeting is a constrained discretion in monetary policies.

This monetary regime is a "compromise" between the classical mainstream, which argues that inflation is always a monetary phenomenon, hence must follow strict rules; and the 
Keynesians mainstream, which argues that inflation is not caused by the higher amount of money than goods, but because of the number of worker seeking for job exceed the available employment capacity. With this context, monetary policies are responsible to ensure the equilibrium between demand and supply of the economy, hence must be conducted wisely (discretion) in accordance with the current development. The compromise is, in the long run the monetary policy follow the rules, whereas in the short run the monetary policies may have discretion.

\subsection{Conventional Monetary Policy Transmission}

From the conventional perspective, the monetary policy can be transmitted through interest rate channel, credit line, exchange rate, asset prices, and expectations channel. The use of interest rate instruments in inflation targeting, put the interest through pass-through as important topic.

Models for interest rate pass-through have been developed for a long time. The model developed by Rousseas (1985), marginal costing pricing model, argue that changes in bank interest rates will be forwarded in the form of changes in interest rates to their customers because it reflects the changes of bank's marginal cost. This model is still considered as the best model to explain the interest rate pass-through from policy rates to bank interest (Egert et al, 2006). The general representation of the model equation is:

$$
b r_{n, t}=\gamma_{0}+\gamma m r_{n, t}
$$

Where $b r$ is interest rates set by banks; $\gamma 0$ is mark-up; and $m r$ is the marginal cost price, substituted with the market interest rate.

Several factors can explain the spread between the retail rate and the marginal cost of funds, such as the level of competition (the higher the competition the lower the spread), the difference in interest rates for different customers, and the asymmetric information between borrowers and lenders. According to Bredin (2002), there are three categories of variable that may affect the level and speed of pass-through from policy rates to bank interest rates; monetary policies, the level of banking competition, and other factors.

On empirical ground, some studies use a standard single equation Error Correction Model (ECM), for example Mojon (2000), Bredin (2001), de Bondt (2002), Espinosa-Vega and Rebucci (2003), Chmielewski (2004), Tiemen (2004), Horvath et.al. (2005), Betancourt et.al. (2008), and van Leuvensteijn et.al. (2008). The estimated equation proposed by de Bondt (2002) is: 


$$
\Delta b r_{n, t}=\eta_{n}+\alpha \Delta m r_{t}-\beta\left(b r_{n, t-1}-\gamma m r_{t-1}\right)+\varepsilon_{n, t}
$$

where $\alpha$ is pass-through parameter in one period, and $\beta$ is speed of adjustment parameter for pass-through effect. This estimation was conducted in two steps; hence two-step ECM method. The first step calculates the residual from the first equation $\left(b r_{n, t-1}-2 m r_{t-1}\right)$. The second step estimates the Equation 2 by including the residual value $\left(b r_{n,-1-1}-2 m r_{t-1}\right)$.

The standard ECM was then developed to non-linear or asymmetric ECM, applied by Scholnick (1999) and Chmielewski (2004), with the following modification on Equation 2:

$$
\Delta b r_{n, t}=\eta_{n}+\alpha \Delta m r_{t}+\beta_{1} e c t_{n, t-1}^{+}+\beta_{2} e c t_{n, t-1}^{-}+\varepsilon_{n, t}
$$

where $\beta_{1}$ is positive adjustment level at $t$ and $\beta_{2}$ is negative adjustment level at $t$.

Standard ECM are also developed in the form of extended ECM to detect the complete or incomplete pass-through, as in Weth (2002) and Chmielewski (2004), with the following modification on Equation 2:

$$
\Delta b r_{n, t}=\eta_{n}+\alpha \Delta m r_{t}+\beta\left(b r_{n, t-1}-m r_{t-1}\right)+\delta b r_{n, t-1}+\varepsilon_{n, t}
$$

For $\delta \neq 0$ reflects an incomplete pass through.

Another version of the ECM is the auto regressive distributed lag (ARDL), proposed by Crespo-Cuaresma et.al.(2004), Burgstaller (2005), Lie et.al. (2005), Egert et.al. (2006), and Marotta (2007), with the following model:

$$
\Delta b r_{t}=\delta_{0}+\sum_{j=1}^{p-1} \mu_{j} \Delta b r_{t-j}+\sum_{k=0}^{q} \kappa_{k} \Delta m r_{t-k}+\gamma\left(b r_{t-1}-\lambda m r_{t-1}\right)+\varepsilon_{t}
$$

where $\gamma$ is the speed of adjustment, and $\lambda$ is the long run multiplier (pass-through).

Another development of the standard ECM, such as Dynamic Ordinary Least Squares models or DOLS, threshold autoregressive or TAR models (Horvath et.al., 2005), transfer function approach model (Qayyum et.al., 2005), dynamic seemingly unrelated regression models or DSUR (Sorensen and Werner, 2006), and the panel ARDL models (Aydin, 2007).

On empirical ground, Espinosa-Vega and Rebucci (2003) compared Chile andother countries (Euro, Canada, U.S., Australia and New Zealand), Egertet.al. (2006) used a sample offive countriesin Central and EasternEurope, or CEE-5 (Czech Republic,Hungary, Poland, 
Slovakia, and Slovenia), while Sorensen and Werner (2006) used a sample of Euro area countries with the dynamic data panel and ECM method.

Egert et.al.(2006) foundthat the interest rate pass-through effect in the CEE-5 was low and decreased along years of observation, due to the absence of co-integration between the policy rate and the bank interest rates (short and long run), and is expected to continue declining in the future.

Sorensen and Werner (2006) found a large heterogeneity in the Euro countries both on the long-run pass-through equilibrium and its speed of adjustment. These results also confirm the slow and incomplete adjustment process of bank interest rate on policyrate.

Horvath et.al. (2005) found corporate lending rates adjusted quickly and completely to the changes of interest rate policy, while the deposit rates and household loans adjusted slowly and incompletely. Qayyum et.al. (2005) found the pass-through of policy rate (T-Bills rate) to the call money rate is complete in a month, while the pass-through from policy rates to deposit rates and bank loans take longer. Liu et.al. (2005) concluded that there is a complete long run pass-through for some interest rates in New Zealand, and generally, confirmed that the policy rates have greater influence on short-run interest rates and that an increase in transparency increases the effectiveness of monetary policy.

Recent studies link the interest rate pass-through to the implementation of Euro (Marotta, 2007), to the macro-economic variables that also affect interest rates (Betancourt et.al., 2008), to the optimal monetary policy (Kobayashi, 2008), and to the competition among banks (Van Leuvensteijnet.al., 2008).

Marotta (2007) examined the structural breaks in the interest rate pass-through from policy rates to bank lending rates and the process of unification of the Euro. The result shows that the EU members have different speeds of adjustment to the Euro unification in the January 1999, and they adjusted to the new monetary regime slowly. He also found that the interest rate pass-through in EU countries are incomplete, which means that the uniform monetary policy is less effective. These results are contrary to the economic intuition that thed ecline in the volatility of policy rate (money market rate) will faster the transmission from policy rate to the bank's interest rate.

Betancourt (2008) conducted a study on interest rate pass-through in Colombia from micro banking perspective with monthly data during 1999-2006, using the single equation error correction model (EC) and the vector autoregressive model (VAR). It is based on the microeconomic theory that the effect of interest rate policy on banking is acomplex process and also depends on the macroeconomic variables. The result of the two models supports the hypo thesis that besides interest rate policy, macroeconomic variables also affect the transmission mechanism of monetary policy to the banking interest rate. In addition, the EC 
model results indicate incomplete pass-through, where as the VAR model indicates complete pass-through.

Kobayashi (2008) analyzed the incomplete interest-rate pass-through in Euro area and the optima Imonetary policy. He stated that if not all commercial banks directly respond to changes in interest rates policy, then monetary policy will provide different impact on the economy. The results show that if only part of banking loan rate adjust for changes in policy rate, then fluctuations in average lending rate raises the cost of welfare, then the central bank needs to stabilize this fluctuation policy rates moothing. However, drastic changes inpolicy rate are still required when there is a shock that directly affects interest rates.

Van Leuvensteijnet.al.(2008) conducted a study on the impact of bank competition towards the interest rate pass-through in the Euro area over the periods of 1994-2004 in two stages. The first stage of the method was to measure the level of competition using Boone indicator. The second stage measured the effect of competition on interest rate pass-through using panel error correction model (ECM) method. The first stage showed that higher competition increase the spread between interest rate policy (market rate) and bank interest rates, particularly credit. The second stage's results showed that the higher the level of banking competition in a country, the bank sets loan interest rates in accordance with the policy rate. In addition, the pressure of competition is more severe in loans than in deposits. Bank interest rates in a more competitive market respond stronger to changes in interest rate policy. The implication is the regulation to increase banking competition will improve the effectiveness (strength and speed) of transmission mechanism of monetary policy.

The results of interest rate pass-through with the standard ECM method for some countries are presented in Table 3. Overall, the results of IRPT are not the same across countries. One thing in common about the interest rate pass-through across countries is that the level of shortrun pass-through is lower than the level of long-run pass-through, except for the US, where the level of short-run pass-through rate is equal to the long-run pass-through. The level of pass-through effect between deposits and loans vary widely. In some countries, the pass-through effect on deposit is lower than the loans, in some countries the opposite occurs, and in the other countries, the pass-through effect on deposit is equal to the effect on loans. Thus, in this case we can not draw general conclusion. Similarly, the speed of adjustment of the interest rate pass-through is also varying across countries. 


\begin{tabular}{|c|c|c|c|c|c|c|c|c|}
\hline \multicolumn{9}{|c|}{$\begin{array}{c}\text { Table } 3 . \\
\text { Interest Rate Pass-Through using Standard ECM on selected Countries }\end{array}$} \\
\hline \multirow{2}{*}{ Author } & \multirow{2}{*}{ Country } & \multicolumn{2}{|c|}{ Short Term } & \multicolumn{2}{|c|}{ Long Term } & \multirow{2}{*}{ Adjustment } & \multirow{2}{*}{\multicolumn{2}{|c|}{ Notes }} \\
\hline & & Deposit & Loan & Deposit & Loan & & & \\
\hline $\begin{array}{l}\text { Bredin et al. } \\
2001\end{array}$ & Ireland & & & & $0.64-0.88$ & $0.25-0.72$ & Str Break & \\
\hline $\begin{array}{l}\text { De Bondt } \\
2002\end{array}$ & Euro area & $0.32-0.35$ & $0.13-0.54$ & $0.35-0.98$ & $0.92-1.53$ & $\begin{array}{l}\text { S 3-15 month } \\
\text { P 3-10 month }\end{array}$ & $\begin{array}{l}\mathrm{S} \approx \mathrm{P} \\
\mathrm{Pdk}<\mathrm{Pjg}\end{array}$ & $\mathrm{S}<\mathrm{P}$ \\
\hline \multirow{6}{*}{$\begin{array}{l}\text { Espinosa- } \\
\text { Vega \& } \\
\text { Rebucci } 2003\end{array}$} & Chile & $0.20-0.68$ & $0.18-0.63$ & $0.39-0.68$ & $0.55-0.88$ & $\begin{array}{l}\text { S } 1 / 2-4 \text { month } \\
\text { P } 2 / 3-2 \text { month }\end{array}$ & $\begin{array}{l}S \approx P \\
P d k<P j g\end{array}$ & $\mathrm{~S}<\mathrm{P}$ \\
\hline & Euro & $0.27-0.57$ & $0.18-0.43$ & $0.60-0.72$ & $0.57-0.82$ & $\begin{array}{l}\text { S } 11 / 2-17 \text { month } \\
\text { P } 3-11 \text { month }\end{array}$ & $\begin{array}{l}\text { S }>\text { P } \\
\text { Pdk }<\text { Pjg }\end{array}$ & $\mathrm{S}>\mathrm{P}$ \\
\hline & Canada & $1.05-1.13$ & $0.46-0.83$ & $0.93-0.98$ & $0.24-1.01$ & $\begin{array}{l}S \approx 0 \text { month } \\
P_{-}-4 \text { month }\end{array}$ & $\begin{array}{l}\mathrm{S}>\mathrm{P} \\
\mathrm{Pdk} \approx \mathrm{Pjg}\end{array}$ & $\mathrm{S}>\mathrm{P}$ \\
\hline & US & $0.84-1.00$ & 0.86 & $0.64-1.00$ & 1.00 & $\begin{array}{l}\text { S } 0-2 \text { month } \\
\text { P } 0.2 \text { month }\end{array}$ & $\begin{array}{l}\mathrm{S} \approx \mathrm{P} \\
\mathrm{Pdk} \approx \mathrm{Pjg}\end{array}$ & $\mathrm{S}<\mathrm{P}$ \\
\hline & Australia & $0.40-0.87$ & 0.46 & $0.67-0.81$ & 1.09 & $\begin{array}{l}S_{P}-1.4 \text { month } \\
\text { P } 3.86 \text { month }\end{array}$ & $\begin{array}{l}S \approx P \\
P d k<P j g\end{array}$ & $\mathrm{~S}<\mathrm{P}$ \\
\hline & $\begin{array}{l}\text { New } \\
\text { Zealand }\end{array}$ & $0.34-0.42$ & 0.21 & $0.71-0.74$ & 0.77 & $\begin{array}{l}\text { S 2-2_ month } \\
\text { P } 2 \text { month }\end{array}$ & $\begin{array}{l}\mathrm{S}>\mathrm{P} \\
\mathrm{Pdk}<\mathrm{Pjg}\end{array}$ & $S \approx P$ \\
\hline $\begin{array}{l}\text { Chmielewski } \\
2004\end{array}$ & Polandia & $0.22-0.57$ & $0.47-0.68$ & $0.75-0.88$ & $0.85-1.02$ & $\begin{array}{l}\text { S } 1-4 \text { month } \\
\text { P 1_-5 month }\end{array}$ & $\begin{array}{l}\mathrm{S}<\mathrm{P} \\
\mathrm{Pdk}<\mathrm{Pjg}\end{array}$ & $\mathrm{S}<\mathrm{P}$ \\
\hline \multirow{6}{*}{ Tieman 2004} & Czech & $0.09-0.02$ & $0.07 \quad 0.19$ & $0.80 \quad 0.49$ & $0.76 \quad 0.65$ & $\begin{array}{l}\text { S 1_ } 8.1 \text { month } \\
\text { P } 2.4 \quad 4.4 \text { month }\end{array}$ & $\begin{array}{l}S \approx P \\
P d k<P j g\end{array}$ & $S \approx P$ \\
\hline & Hungary & 0.220 .07 & $-0.15 \quad 0.01$ & 0.820 .90 & $1.10 \quad 0.67$ & $\begin{array}{l}\text { S } 1.62 .8 \text { month } \\
\text { P 10_9_ month }\end{array}$ & $\begin{array}{l}\mathrm{S} \neq \mathrm{P} \\
\mathrm{Pdk}<\mathrm{Pjg}\end{array}$ & $\mathrm{S} \approx \mathrm{P}$ \\
\hline & Polandia & 0.290 .23 & $0.18 \quad 0.10$ & $0.98 \quad 0.91$ & $0.85 \quad 0.96$ & $\begin{array}{l}\text { S } 36.82 \text { month } \\
\text { P } 6.410 \text { month }\end{array}$ & $\begin{array}{l}\mathrm{S}>\mathrm{P} \\
\mathrm{Pdk}<\mathrm{Pjg}\end{array}$ & $S \approx P$ \\
\hline & Romania & $\ldots . \quad-0.30$ & $-0.46-044$ & $\begin{array}{ll}\ldots & -0.78\end{array}$ & $0.80 \quad 0.73$ & $\begin{array}{l}\text { S ..... 5_month } \\
\text { P 3_ } 4 \text { month }\end{array}$ & $\begin{array}{l}\mathrm{S} \approx \mathrm{P} \\
\mathrm{Pdk}<\mathrm{Pjg}\end{array}$ & $\mathrm{S} \approx \mathrm{P}$ \\
\hline & Slovak & $0.04 \quad 0.23$ & -0.020 .07 & 1.001 .27 & 1.620 .79 & $\begin{array}{l}\text { S } 6.922 \text { 2_ month } \\
\text { P 9_ } 5.8 \text { month }\end{array}$ & $\begin{array}{l}\mathrm{S}>\mathrm{P} \\
\mathrm{Pdk}<\mathrm{Pjg}\end{array}$ & $S \approx P$ \\
\hline & Slovenia & $0.16 \quad 0.11$ & $0.16 \quad 0.15$ & 1.411 .57 & $2.08 \quad 1.85$ & $\begin{array}{l}\text { S 5_6_ month } \\
\text { P } 11.2 \text { 9_month }\end{array}$ & $\begin{array}{l}\mathrm{S} \approx \mathrm{P} \\
\mathrm{Pdk}<\mathrm{Pjg}\end{array}$ & $\mathrm{S} \approx \mathrm{P}$ \\
\hline $\begin{array}{l}\text { Horvath et al. } \\
2005\end{array}$ & Hungary & 0.410 .64 & $0.05 \quad 0.67$ & $0.86 \quad 0.87$ & $\begin{array}{ll}0.81 & 0.98\end{array}$ & $\begin{array}{l}\text { S 3 - } 2 \text { month } \\
\text { P 4 - } 2 \text { month }\end{array}$ & $\begin{array}{l}\mathrm{S} \approx \mathrm{P} \\
\mathrm{Pdk}<\mathrm{Pjg}\end{array}$ & $\mathrm{S} \approx \mathrm{P}$ \\
\hline
\end{tabular}


Table 4 gives the variation of the level of pass-through on deposit and loans across countries. However, in general there isa certain pattern. In the short run, the pass-through deposit is equal to or greater than the pass-through loans. In the long run, the pass-through deposit is equal to or smaller than the pass-through loans. Most empirical studies show that the level of pass-through deposit equal to the level of pass-through loans in the short and long run.

\begin{tabular}{|c|c|c|}
\hline \multicolumn{3}{|c|}{$\begin{array}{c}\text { Table } 4 . \\
\text { Interest Rate Pass-Through using Standard ECM on Selected Countries }\end{array}$} \\
\hline Deposit < Loan & Deposit $\approx$ Loan & Deposit > Loan \\
\hline Chile (Pjg) & Chile (Pdk) & \\
\hline \multirow[t]{2}{*}{ Euro area $(\mathrm{Pjg})$} & Euro area (Pdk) & Euro (Pdk, Pjg) \\
\hline & & Canada (Pdk, Pjg) \\
\hline US (Pjg) & US (Pdk) & \\
\hline \multirow[t]{3}{*}{ Australia (Pjg) } & Australia (Pdk) & \\
\hline & New Zealand (Pjg) & New Zealand (Pdk) \\
\hline & Czech (Pdk, Pjg) & \\
\hline \multirow[t]{5}{*}{ Polandia (Pdk, Pjg) } & Polandia (Pjg) & Polandia (Pdk) \\
\hline & Romania (Pdk, Pjg) & \\
\hline & Slovak (Pjg) & Slovak (Pdk) \\
\hline & Hungary (Pdk, Pjg) & \\
\hline & Slovenia (Pdk, Pjg) & \\
\hline
\end{tabular}

\subsection{Islamic Monetary Transmission Policy}

Transmission of monetary policye merged since the separation of the monetary authority from fiscal authorities. Monetary authorities evolved in line with the development of central bank from circulation bank (issuing paper money or fiat money), which marked by the establishment of Bank of England (BOE) in 1694 (Capie, 1994). Because of its inflationary paper money (since it has no intrinsic value) then the task of central bank increased, including setting the money supply to control the value of currency or inflation. This is not necessary when the money has intrinsic value, like the gold Dinar and silver Dirham during Islamic caliphate. The last Khilafah Islamiyah, the Ottoman dynasty in Turkey, collapsed in 1924 (Islahi, 2004).

In conventional economic domination with its central bank and fiat money, Islamic economics grow in Muslim-majority countries within the system of paper money and central banks. Therefore, Islamic monetary system with its policies and transmission processes also grew. A pioneer of the theory of contemporary Islamic monetary economics is Muhammad Umer Chapra in his book "Towards a Just Monetary System (1985)". 
The setting of contemporary Islamic financial institutions are not much different from the setting of conventional financial institutions, hence the Islamic monetary policy instruments are also similar with the instruments of the conventional one. Since both systems have similar and also different instruments, the Islamic monetary policy transmission can be similar or different from the conventional one. Chapra (1985) did not discuss specifically the issue of Islamic monetary policy transmission. Further development of Islamic monetary theory also does not mention it; including pass-through or its channels (see Siddiqui, 2007).

However, few empirical studies a rise to see the Islamic monetary policy transmission characteristics. Sukmana and Kassim(2010) was an initial attempt to determine the transmission of monetary policy through financing channel to economic growthin Malaysian Islamic banking system, which is simply defined as follows:

$$
I P I=f(I F, I D, O N I G H T)
$$

Where IP is industrial production index, IF is Islamic financing, ID is third party fund collected in Islamic bank, and ONIGHT is overnight interbank interest rate, representing the monetary policy.

The same framework has been carried out by Ascarya (2010) for the case of Indonesia in order to determine the transmission of monetary policy to the ultimate goal of monetary policy (namely economic growt hand stability of the money), via financing channel in Islamic banking. The model is simply defined as follows:

$$
I P I=f(I F I N, I D E P, P U A S, S B I S)
$$

and

$$
C P I=f(I F I N, I D E P, P U A S, S B I S)
$$

Where IPI is industrial production index, CPI is consumer price index, IFIN is Islamic bank financing, IDEP is third party financing or funds in Islamic bank and PUAS is interest rate of Islamic interbank money market.

In addition, Ayuniyyah, et.al.(2010) examined the multiple transmission of monetary policy in Indonesia in order to grow the economic. The model is simply formulated as:

$$
I P I=f(n I F I N, n C C R D, i I F I N, i C C R D, n I D E P, n C D E P, i I D E P, i C D E P, S B I S, S B I)
$$


where IPI is industrial production index, $n I F I N$ is total Islamic bank financing, $n C C R D$ is total conventional bank credit, nIDEP is financing or funds from an Islamic third part, $n C D E P$ is total financing or funds from a conventional bank, iIDEP is Islamic banking deposits yield, iCDEP is conventional banking deposits yield, $S B I S$ is the yields of Syariah Certificates of Bank of Indonesia, and SBI is the yields of Certificates of Bank Indonesia.

The conventional interest rate pass-through model (Egerti, 2006) was modified to formulate the Islamic pass-through rate policy model. Equation (1) is modified as follows:

$$
i b r_{n, t}=\gamma_{0}+\gamma i m r_{n, t}
$$

Where ibr is funding or financing yield set by Islamic banks, $\gamma 0$ is mark-upand imr is the marginal cost price, substituted with market return.

For equation to estimate, we refer Bde Bondt (2002), with the following modification:

$$
\Delta i b r_{n, t}=\eta_{n}+\alpha \Delta i m r_{t}-\beta\left(i b r_{n, t-1}-\gamma i m r_{t-1}\right)+\varepsilon_{n, t}
$$

Where $\alpha$ is pass-through parameter for one period, and $\beta$ is the speed of pass-through adjustment.

The first step is to calculate the residual of Equation $10\left(\mathrm{ibr} r_{n,-1-}-\gamma \mathrm{im} r_{t-1}\right)$. The second step is use the residual $\left(i b r_{n, t-1}-\right.$ yimr $\left._{t-1}\right)$, then estimate Equation 11.

\section{METHODOLOGY}

This paper uses quantitative approach to analyze monetary policy in a dual financial system; conventional and Islamic. Empirical model that is built refers to the conceptual framework as illustrated in Figure 4.

Dual monetary policy in Indonesia used multiple monetary policy instruments, namely Certificate of Bank of Indonesia or SBI-based interest rates for conventional system, and Islamic SBI or SBIS-based fee for Islamic banking, which are still referring to the SBI rate. SBI interest rate and SBIS fee are policy rates.Policy rates will affect the funding and the bank financing through the interbank money market both in conventional and Islamic banking, then will affect the costof fund channeling. Expansion of credit and financing will finally affect the level of output and inflation. 


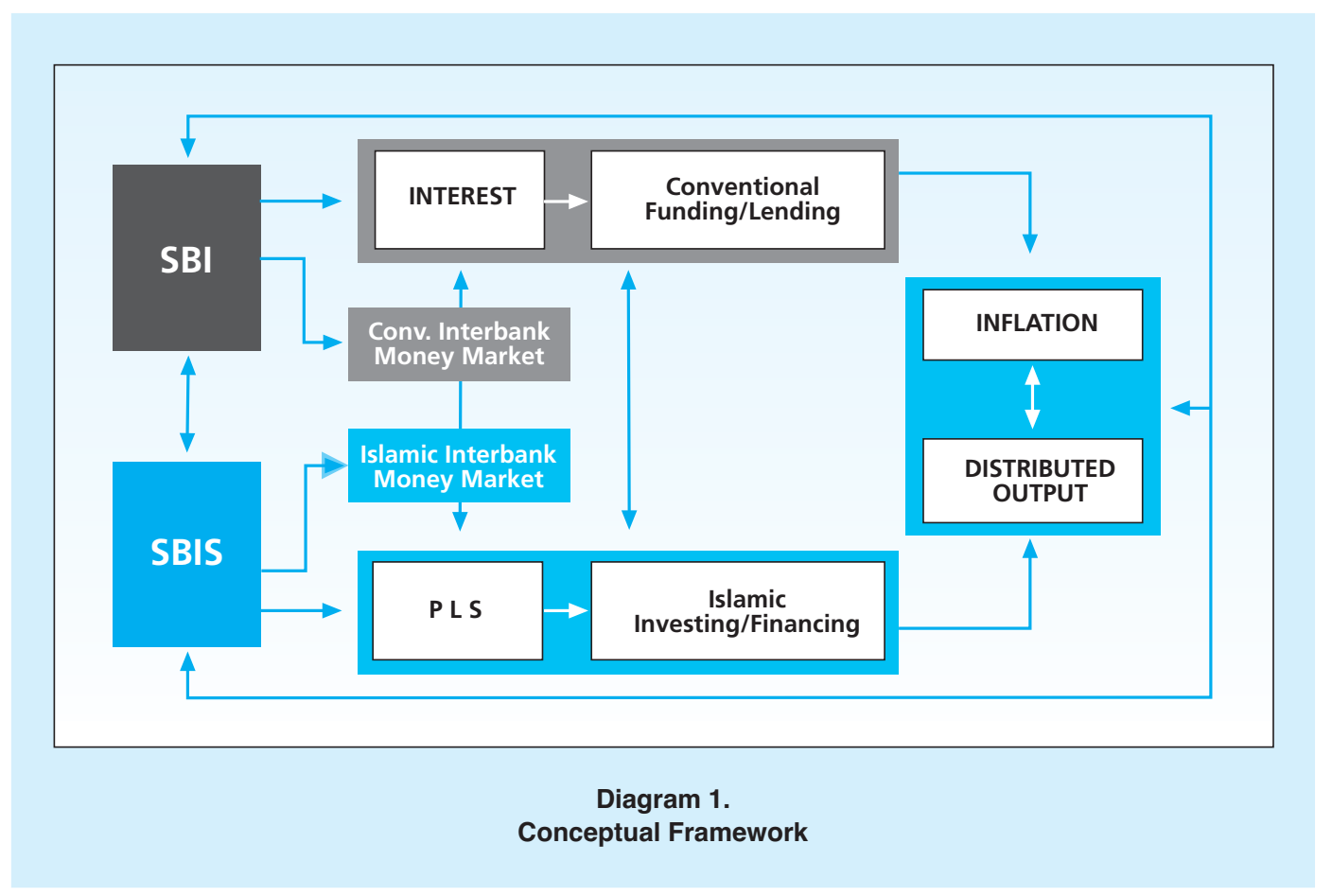

\subsection{Data and Variables}

The data used inthis study is monthly time series data during the period of January 2003 to September 2009, obtained from SEKI, DSM, and DPbS Bank Indonesia.

To answer the first research question, we use the following data:

1. $\mathrm{SBI}_{\mathrm{t}} \quad$ : Conventional policy rate, a1-month $\mathrm{SBI}$ obtained from DSM-BI.

2. SBIS $_{t} \quad:$ Islamic policyrate, using the SWBI bonus and SBIS fee (since April 2008), obtained from Statistics of Islamic Banking and DSM-BI.

3. PUAB ${ }_{t} \quad:$ Conventional interbank money market rate, obtained from the DSM-BI.

4. PUAS $_{\mathbf{t}} \quad$ : Islamic interbank money market, obtained from the DSM-BI.

5. INT $\quad$ : Loan (working capital) interest of conventional banks, obtained from the DSM-BI.

6. PLS $_{\mathbf{t}} \quad$ : The rate of profit and loss sharing for financing (Musharaka + Mudharabah) in Islamic bank, obtained from the Directorate of Islamic Banking BI.

7. LOAN $_{\mathrm{t}} \quad$ : Total value of conventional bank loan, obtained from the Indonesian Banking Statistics Bl.

8. FINC F $_{\mathrm{t}} \quad$ : Total financing of Islamic banks, obtained from Islamic Banking Statistics BI.

9. $\mathrm{IHK}_{\mathrm{t}} \quad$ : Inflation rate obtained from SEKI BI. 


\subsection{Estimation Techniques}

This study will use several estimation techniques, namely Granger Causality and Vector Auto regression (VAR)Nector Error Correction Model (VECM), Standard Error Correction Model with two-steps, and descriptive analysis.

To answer the first research question (identify the dual monetary policy transmission channel in Indonesia, both through the conventional and Islamic system, and also their link), we use the Granger Causality technique. Causality relationships among the variables are based on the following conceptual framework:

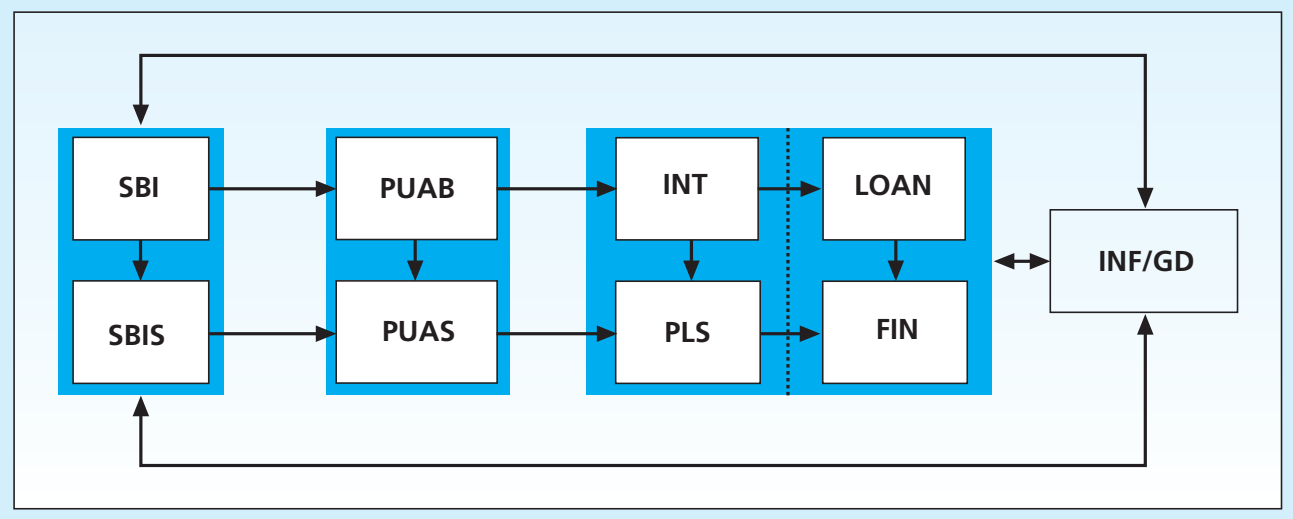

Diagram 2.

Dual Monetary Transmission Channel (Conventional and Syariah)

To answer the second research question, we canuse the Vector AutoRegression (VAR). In the presence of cointegration, we will usethe Vector Error Correction Model (VECM).

VAR is a system of $n$ equation, with $n$ endogenous variables. Each endogenous variable is explained by its own lag, current value of other endogenous variable, and the lag of other endogenous variables. Therefore, in the context of modern econometrics, VAR is considered as a multivariate time-series that treat all variable endogenously since there is nocertainty if the variable is actually exogenous, and is fully rely on the data to explain. Sims (1980) argues that if there is a true simultaneity among a number of variables, then the variables must be treated equally and there should be no a priori distinction between endogenous and exogenous variables. Enders (2004) formulated the simple first-order bivariate system as follows:

$$
\begin{aligned}
& y_{t}=b_{10}-b_{12} z_{t}+\gamma_{11} y_{t-1}+\gamma_{12} z_{t-1}+\varepsilon_{y t} \\
& z_{t}=b_{20}-b_{21} y_{t}+\gamma_{21} y_{t-1}+\gamma_{22} z_{t-1}+\varepsilon_{z t}
\end{aligned}
$$


Assuming that $y_{t}$ and $z_{t}$ is stationary, $\varepsilon_{y t}$ and $\varepsilon_{z t}$ are white noise disturbances with standard deviation $\sigma_{y}$ and $\sigma_{z}$; while $\varepsilon_{y t}$ and $\varepsilon_{z t}$ are white noise and uncorrelated disturbance. Meanwhile, we can write the standard form of the primitive model above as follows.

$$
\begin{aligned}
& y_{t}=a_{10}+a_{11} y_{t-1}+a_{12} z_{t-1}+e_{y t} \\
& z_{t}=a_{20}+a_{21} y_{t-1}+a_{22} z_{t-1}+e_{z t}
\end{aligned}
$$

$e_{y t}$ and $e_{z t}$ are the combination of $\varepsilon_{y t}$ and $\varepsilon_{z t}$. The primitive form is called the structural VAR, and the standard form is called VAR. Detail explanation on transforming the primitive to standard forms is available in Enders(2004). The general VAR model can be presented as:

$$
x_{t}=\mu_{t}+\sum_{i=1}^{k} A_{i}+X_{t-1}+\varepsilon_{t}
$$

$x_{t}$ is the $(\mathrm{n} \times 1)$ vector of endogenous variable; $\mu_{t}$ is the vector of exogenous variable, including intercept andtrend; $A_{i}$ is ( $\mathrm{n} \times \mathrm{n}$ ) coefficientmatrix ; and $\varepsilon_{t}$ is the residual vector. In a simple bivariate system of $y_{t}$ and $z_{t}$, the variable $y_{t}$ is influenced by the present and past value of $z_{t^{\prime}}$ while $z_{t}$ is influenced by the present and the past value of $y_{t}$.

To overcome the shortcoming of first-differenced VAR and to regain long-run relationships between variables, we can use Vector Error Correction Model (VECM), as long as these variables are co-integrated. Inserting the original equation in level into the new equations, we have :

$$
\begin{aligned}
& \Delta y_{t}=b_{10}+b_{11} \Delta y_{t-1}+b_{12} \Delta z_{t-1}-\lambda\left(y_{t-1}-a_{10}-a_{11} y_{t-2}-a_{12} z_{t-1}\right)+\varepsilon_{y t} \\
& \Delta z_{t}=b_{20}+b_{21} \Delta y_{t-1}+b_{22} \Delta z_{t-1}-\lambda\left(z_{t-1}-a_{20}-a_{21} y_{t-1}-a_{22} z_{t-2}\right)+\varepsilon_{z t}
\end{aligned}
$$

$a$ is the long-runcoefficient, $b$ is the short run coefficient, $\lambda$ is the error correction parameter, and the term in parentheses indicate co-integration between variables $y$ and $z$.

General VECM model scan be presented as follows (Achsani etal, 2005):

$$
\Delta x_{t-1}=\mu_{t}+\prod x_{t-1}+\sum_{i=1}^{k-1} \Gamma_{i} \Delta x_{t-i}+\varepsilon_{t}
$$

$\Pi$ and $\Gamma$ is the function of $A_{i}$. The matrix $\Pi$ can be decomposed into two matrices with dimensions $(n \times r) ; \Pi=\lambda \beta^{T}$, where $\lambda$ is the adjustment matrix and $\beta$ is the co-integration vector, whereas $r$ is the co-integration rank. 
The procedure of VAR analysis is presented Diagram 3. Once the basic data is ready, we transform them into the natural logarithm (In) to obtain consistent and valid results, except for interest rates and profit sharing return. The first test is the unit root test, to determine if the data is stationary or containing trend. If they are stationary at level, we use VAR directly. VAR level can estimate long-run relation ships among variables. If data are not stationary at level, we take the first difference and test if they are stationary. If the data in first difference is stationary, we proceed to test for co-integration among variables. Without co-integration, we can only apply the VAR at first difference, representing the short-run relationships among variables. Without cointegration, the innovation accounting would not be meaningful for the long-run relation ship among variables.

With the presence of co-integration, we can apply the VECM model on data level to obtain the long-run relationships among variables. VECM can estimate the short and the longrun relationships among variables. Within this condition, the innovation accounting for the VAR level and VECM will be meaningful for long-run relationships.

Referring the conceptual framework above, the second issue in this paper will be analyzed by using general VAR model, as in Equation 18. The two models of the dual monetary transmission policy are output models and inflation model.

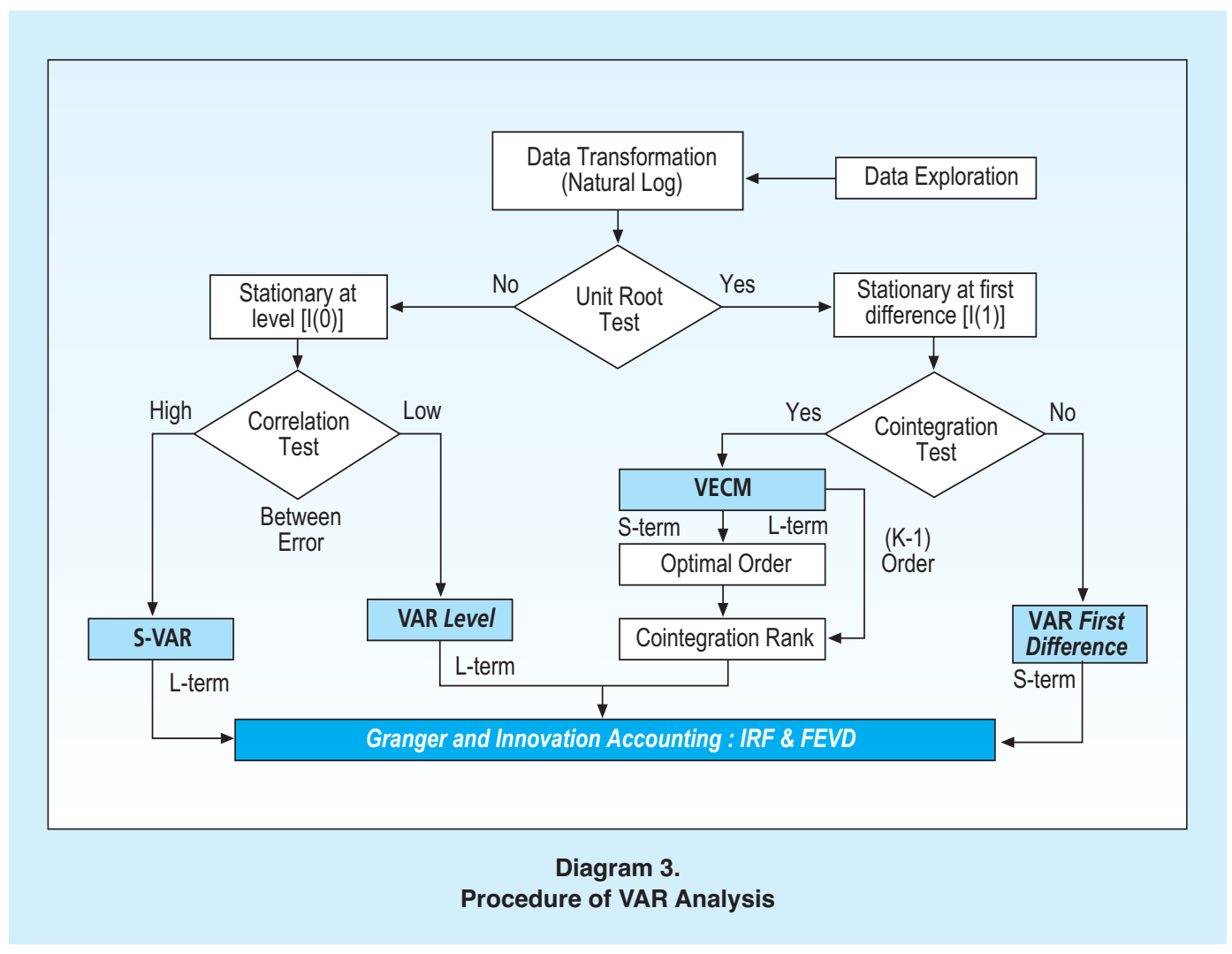


We use impulse response function to analysis the response of endogenous variables on other variables shock in the model. Decomposition variance analysis was also conducted to see the relative contribution of variable in explaining the variability of certain variables. Data of IHK, FINC, and LOAN are transformed into the natural logarithm (In) to obtain valid and consistent results.

\section{RESULTS AND ANALYSIS}

The stationary test show only IPI, FINC, and PUAB are stationary at level, while the remaining variables are stationary on the first difference. The second test is to determine the optimal lag. The first step is determining maximum lag of stable VAR system, where the criterion is stable if all root shave a modulus smaller than one and are located within circle unit (Lutkepohl, 1991). The results show the modulus range of 5 for model Output (IPI) and 6 for the inflation model (CPI); both are located within the unit circle.

The second step is to determine the optimal lag; the shortest lag of Hannan-Quinnon Criterion (HQ) or the Schwarz Information Criterion(SC). The results showed the optimal of one lag for both out put and inflation model.

We apply trace statistics for co-integration test to determine the number of cointegrating equations that explain the long-run relationship. The results show that the Output model has six cointegrated equations, while the Inflation model has four cointegrated equations at critical value of $5 \%$.

\subsection{Granger Causality}

Granger Causality results for conventional monetary policy transmission channel with Output (IPI) as the final target, indicates acontinuity of interest rate channel, from SBI rate to interbank rate (PUAB) and INT, from PUAB to INT and OUTPUT, from INT to the LOAN and back to the SBI and PUAB, and also from LOAN to OUTPUT, then from OUTPUT back to LOAN. In general, the rise in SBI rate increases interest rates and lowers the LOAN and OUTPUT. 


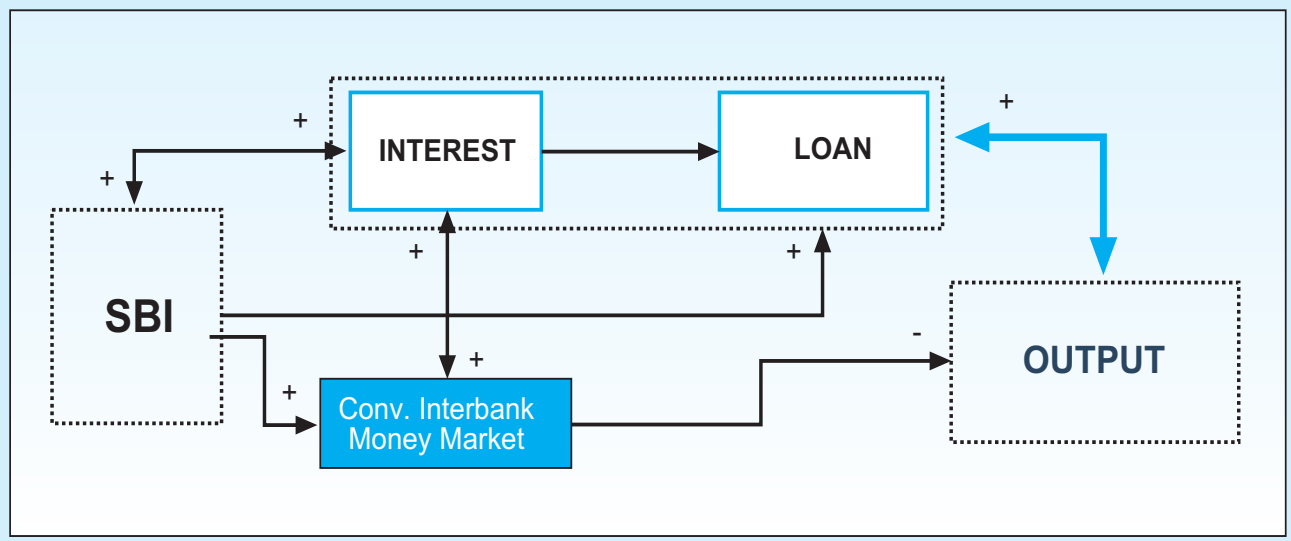

\section{Diagram 4.}

Conventional Monetary Transmission Channel: Output Model

On conventional monetary policy transmission with Output (IPI) as final target, there is no continuity of yield channel from SBIS margin to OUTPUT. SBIS can only affect the financial markets to PUAS. Meanwhile, the PLS affect FINANCING and OUTPUT, and FINANCING affected OUTPUT and PUAS. In general, the SBIS yield only increased the PUAS yield., while the PLS yield increase FINANCING and OUTPUT.

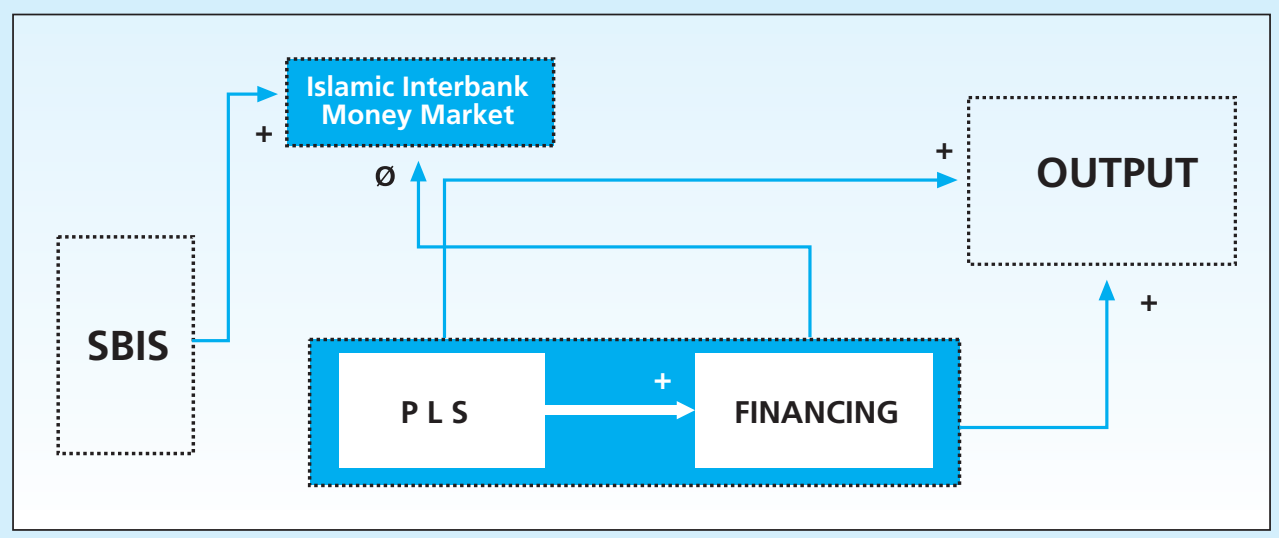

\section{Diagram 5.}

Islamic Monetary Policy Transmission Channel: Output Model

For inflation models, i.e. the monetary policy transmission channel with Inflation (CPI) as the ultimate target, the Granger causality for the conventional system show a continuity of 
interest rate from SBI to PUAB and INT, from PUAB to INT, from INT to LOAN and INFLATION and back again to SBI and PUAB. After that, INFLATION affected SBI. In general the rise in SB increases interest rate, lowers the LOAN and increase INFLATION.

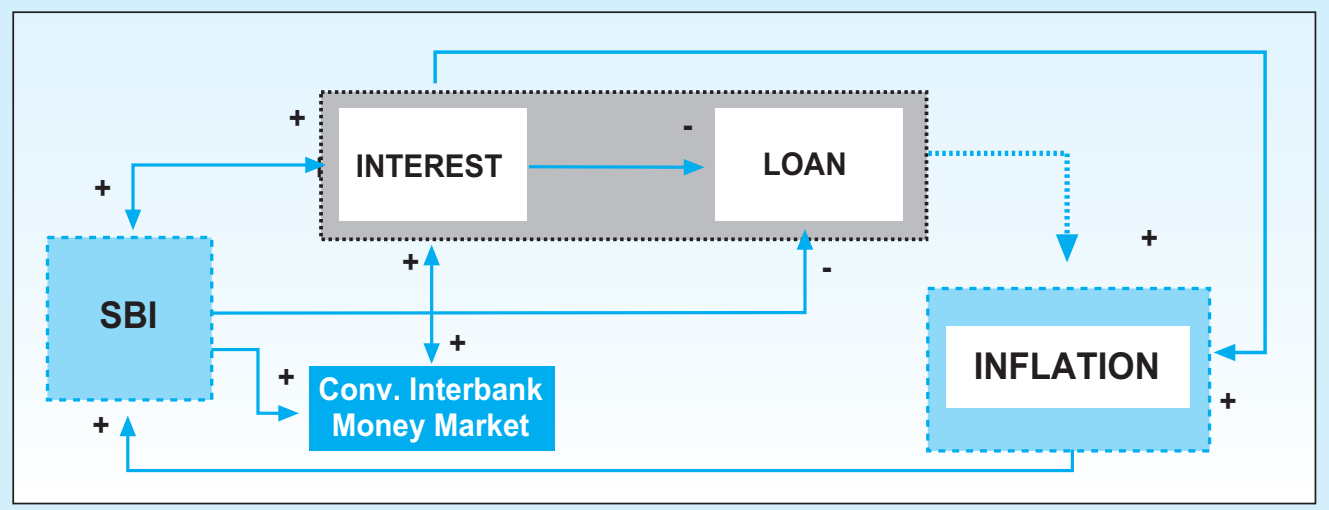

Diagram 6.

Conventional Monetary Policy Transmission Channel: Inflation Model

On the other hand, for the Islamic monetary policy transmission in Inflation model (CPI), the Granger Causality indicated the discontinuity continuous from SBIS yield to inflation. SBIS only affects the yield of PUAS Islamic financial market. Meanwhile, PLS affect FINANCING then FINANCING affects PUAS. In contrast, PUAS, PLS and FINANCING were affected by INFLATION.

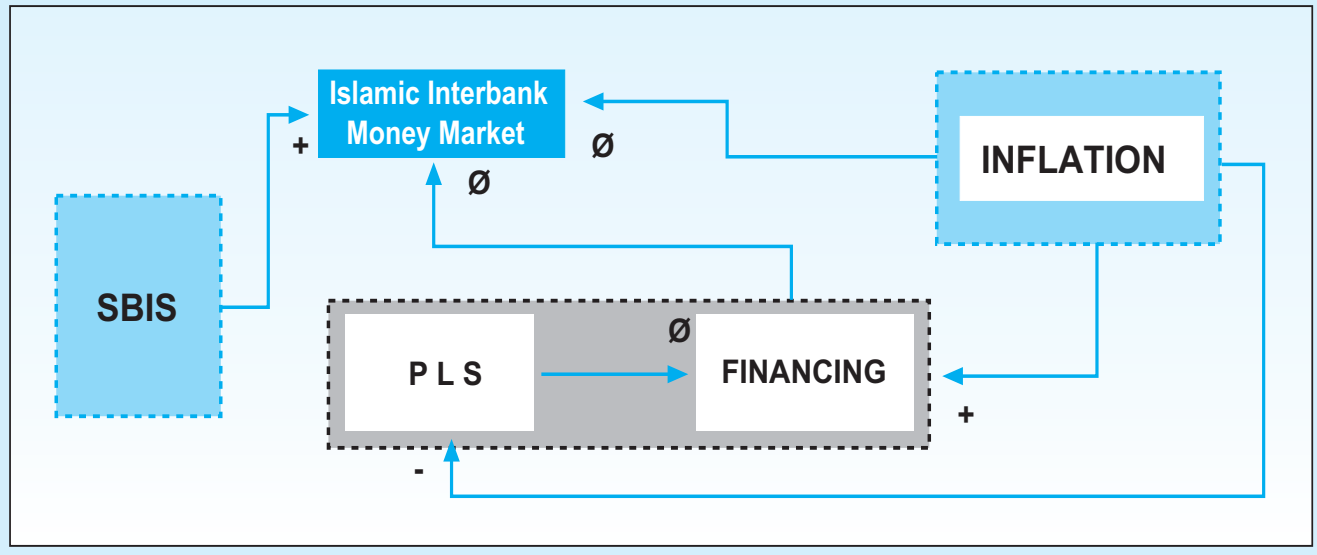

Diagram 7.

Islamic Monetary Policy Transmission Channel: Inflation Model 
In general, the increase of SBIS yield only increase the PUAS yield, while INFLATION lowered the PLS and increase FINANCING.

From the Granger test results above, the conventional monetary policy transmission channel is continuous to OUTPUT, especially loan, because conventional loans are parts of the real sector activities. On the other hand, in Islamic monetary policy transmission channel, the financial sector (SBIS and PUAS) are separated from thereal sector (PLS and FINANCING), and only real sector link to OUTPUT. Worth to note, in conventional side, the increase of SBI reduces the output, since funds are absorbed into the financial sector rather than to the real sector.

In inflation models, the channel of conventional monetary policy transmission is continuous to inflation, while Islamic channel is not. This is possible since the conventional interest-based economy has two dichotomous markets (financial and real sector markets), where the financial market is inflationary. On the other hand, the Islamic one is non-interest-based and focuses on real sector, hence non-inflationary. Therefore, the interest rate (representing the price in the conventional financial sector) affects inflation, while the SBIS (not representing the price in real sector and financial sector) does not affect inflation. When the Islamic system still use SWBI with wadiah akad, the SBIS represent the price in Islamic real sector, and when it use SBIS with ju'alah akad, (profit sharing, which is comparable tothe one-month SBI), SBIS more represent the price of conventional financial sector.

The conventional system affect the Islamic system mainly on loan, since the monetary and financial system in Indonesia is still dominated (97.4\%) by conventional systems, and the real sector is related to credit, not the interest rates. On the other hand, Islamic sides affect the conventional side more from the financing yields (PLS), since it is basically a real sector. Meanwhile, conventional loan interest rates (INT) did not affect the Islamic side since INT is the price of money in the financial sector, which is depends on many variables.

Generally, conventional monetary policy transmission is in line with the theory, while the transmission channel of Islamic monetary policy cannot be clearly identified. However, Islamic instruments using profit and loss sharing, such as mudharabah and musharakah in PLS financing, positively affect the OUTPUT and inflation .

\subsection{Impulse Response Function}

The results of Impulse Response Function (IRF) for the dual monetary policy transmission output models show that all conventional variables, namely credit (LOAN), interest (INT), interbank money market (Interbank) and the policy rate (SBI), permanently lower the output. On the other hand, all the variables of the Islamic Policy Rate, namely financing (FINC), profit sharing (PLS), Islamic interbank money market (PUAS) and Islamic Policy Rate (SBIS), have positive impact in terms of increasing output permanently. 

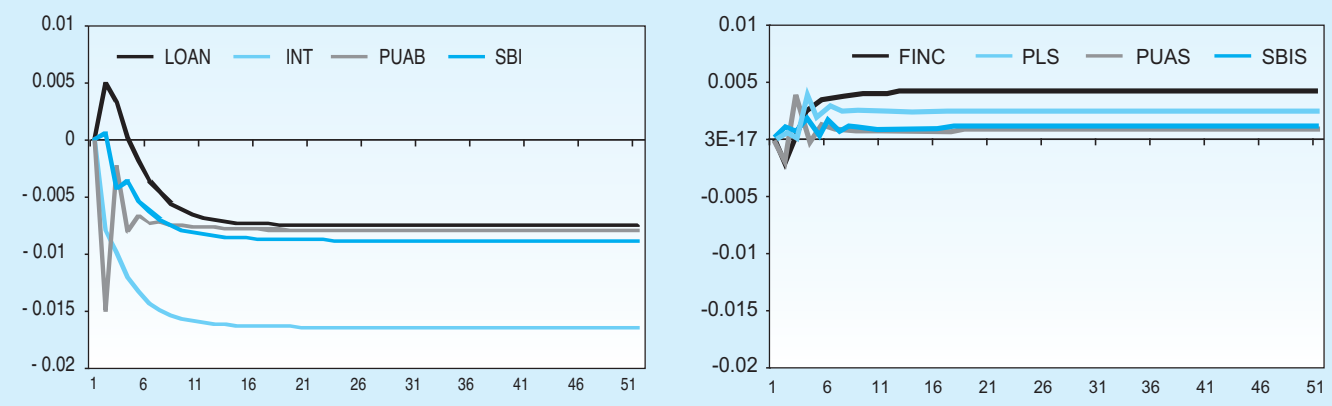

Figure 4.

Impulse Response Function (IRF) for Output Model

The effect of the conventional variables shock towards the output decline and stable after 16-21 periods, while the influence of the Islamic Policy Rate shock towards output decline and stable more quickly after 11-16 periods. Interest rates on conventional systems give the largest negative impact on the output, while Islamic financing (FINC) has the largest positive impact on the output.

For the inflation model (CPI), Impulse Response Function shows that except SBI rate, all conventional variables including the volumeof loan (LOAN), interest (INT), and the interbank money market (PUAB), give inflationary impact on inflation permanently. On the other side, all Islamic variables including financing (FINC), profit and loss sharing (PLS), Islamic interbank money market (PUAB) and Islamic policy rate (SBIS), shows a positive impact in terms of reduce the inflation permanently.
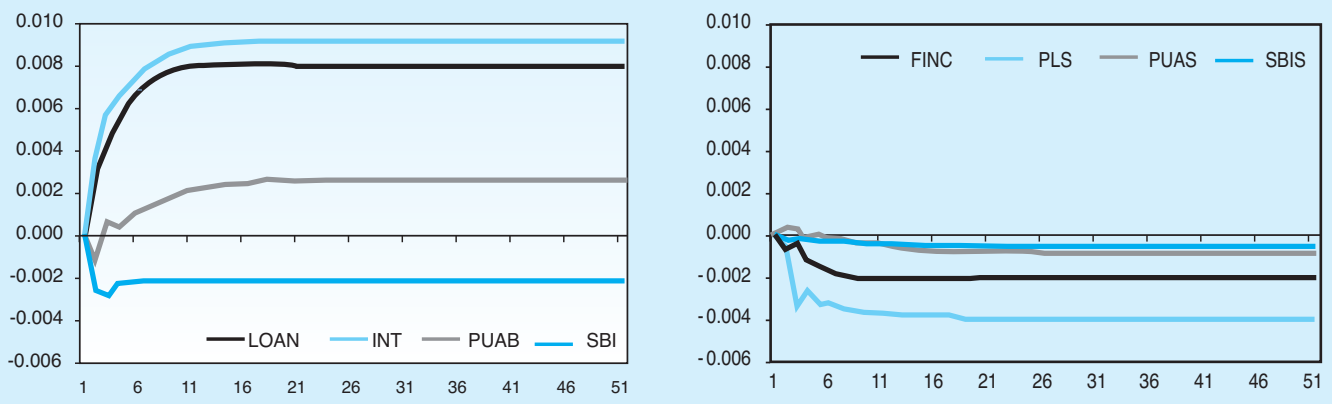

Figure 5.

Impulse Response Function (IRF) for Inflation Model 
The effect of conventional variables shock to inflation decline and stable after 8-21 period, while the influence of Islamic variables shock on inflation decline slightly faster and stable after 9-19 periods. Among conventional variables, the loan interest rate (INT) have the largest negative impact (triggering) on inflation, while the Islamic profit and loss sharing (PLS) have the largest positive impact (reduce) on inflation.

The same result applies for conventional loans (LOAN) and Islamic financing (FINC). Since the credit is influenced by its interest rates, while the financing is affected by its profit sharing, then the loan has a negative impact on inflation and output, while Islamic financing had a positive impact on inflation and output. This pattern also applies for the conventional interbank rate (PUAB) and Islamic interbank yield (PUAS). Since PUAB rate as the reference of conventional banking interest rate give negative impact on inflation and output. On the other hand PUAS positively affect to the inflation and output.

Furthermore, the Islamic monetary policy(SBIS) also showed similar behavior with other Islamic variables; reducing inflation and encouraging the output.

Meanwhile, the effects of shock (increase) in SBI may affect (retain) inflation, but at the same time, it also have a negative impact on output. SBI influence on inflation is the premise of conventional economics to use the SBI as the main monetary instrument in controlling inflation. However, it should be noted that the negative influence of the other three conventiona I variables (PUAB, and LOAN INTEREST) is much larger than the positive effect of SBI on inflation.

The impact of interest rates and inflation are in accordance with the results of empirical studies by Ascarya (2009a and 2009b), where the interest rate is one of the causes of inflation, while profit sharing does not trigger the inflation. The impact of the interest rate and profit sharing towards output was in accordance with Ryandono (2006) and Ascarya et.al. (2007), where the interest rates gave negative impact to output or economic growth, while the profit sharing gave a positive impact to output or economic growth. When the interest rate increased, investment would decrease, so that the output would decrease as well. Meanwhile, when the profit sharing increased, the investment would increase, so that the output would increase as well.

\subsection{Forecast Error Variance Decomposition}

For the model of dual monetary policy transmission channel with the final output (IPI) as the target, the Forecast Error Variance Decomposition (FEVD) indicates that the conventional variables with largest negative contribution (inhibitory) on output includes the interest rate (18:13\%), SBI(5:02\%), Interbank (4:57\%) and LOAN(3:57\%). On the other hand, the Islamic variable sturned out to be apositive contributor on driving the output, though still small, like the FINC (1.12\%) and PLS (0.36\%). 


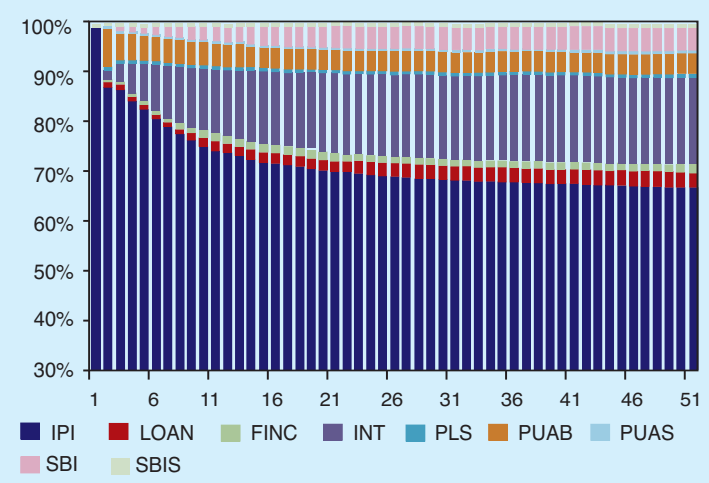

Figure 6. Variance Decomposition of Output

\begin{tabular}{|c|c|c|}
\hline \multirow{3}{*}{$\begin{array}{l}\text { Variable } \\
\text { IPI }\end{array}$} & \multicolumn{2}{|c|}{ VD (\%) } \\
\hline & Syariah & Conv. \\
\hline & \multicolumn{2}{|c|}{67.08} \\
\hline LOAN & & $3.57(-)$ \\
\hline FINC & $1.12(+)$ & \\
\hline INT & & $18.13(-)$ \\
\hline PLS & $0.36(+)$ & \\
\hline PUAB & & $4.57(-)$ \\
\hline PUAS & $0.07(+)$ & \\
\hline SBI & & $5.02(-)$ \\
\hline SBIS & $0.06(+)$ & \\
\hline TOTAL & $1.63(+)$ & $31.29(-)$ \\
\hline
\end{tabular}

For the dual monetary policy transmission with the ultimate goal of inflation (CPI models), the Forecast Error Variance Decomposition (FEVD) shows that the conventional variables with the largest negative contribution or triggering inflation, are interest $(25.23 \%)$, credit volume or LOAN (19:43\%) and the Interbank Money Market (1.87\%), except SBI which contribute positively (inhibitors) on inflation by $1,52 \%$. Meanwhile, Islamic variables are a positive contributor in terms of an inhibitor of Inflation, although still small, such as PLS (4.63\%) and the FINC (1:31\%).

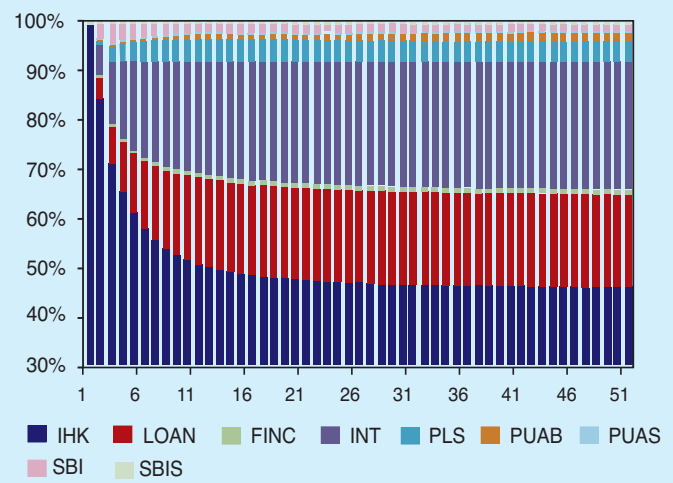

Figure 7. Variance Decomposition of Inflation

\begin{tabular}{l|r|r}
\multirow{2}{*}{ Variabel } & \multicolumn{2}{|c}{ Besaran VD (\%) } \\
\cline { 2 - 3 } IHK & \multicolumn{2}{|c}{$\begin{array}{c}\text { Syariah } \\
\text { Konv. }\end{array}$} \\
\hline LOAN & \multicolumn{2}{|c}{45.74} \\
\hline FINC & $1.31(-)$ & \\
\hline INT & & $25.23(+)$ \\
\hline PLS & $4.63(-)$ & \\
\hline PUAB & & $1.87(+)$ \\
\hline PUAS & $0.19(-)$ & \\
\hline SBI & & $1.52(-)$ \\
\hline SBIS & $0.08(-)$ & \\
\hline TOTAL & $6.21(+)$ & $48.25(-)$
\end{tabular}

The results indicate that, overall, the conventional variables are inhibitors, while Islamic variables are driving force for the economic growth . In aggregate, these conventional variables contributed negatively to economic growth by $31.29 \%$, while the Islamic variables contributed positively to economic growth by $1.62 \%$. 
Meanwhile, in order to achieve price stability or inflation, the conventional variables generally trigger inflation, while the Islamic variables contain it, except for SBI (conventional), which contribute $1.52 \%$ in containing inflation. For inflation targeting, totally generally, the contribution of conventional variables on triggering inflation is $46.53 \%$, while the Islamic variables contain inflation with contribution of $6.21 \%$.

The above results generally show that the conventional variables ( mainly financial sector variables ) naturally lead to inflation and restraint economic growth, while the variables of the Islamic Policy Rate (mainly real sector variables), naturally do not trigger inflation, while encouraging economic growth.

The behavior of SBI in restraining the inflation accord the conventional practice of monetary policy, but fuels inflation through an increase in lending rates and hampering economic growth.

\section{v. CONCLUSION}

This empirical paper provides some important findings. First, based on the test Granger Causality, overall, the flow of conventional monetary policy transmission are in accordance with the theory, while the Islamic monetary policy transmission cannot be clearly identified and is disconnected at PUAS. However, Islamic instruments that uses a contract of profit and loss sharing, such as mudaraba and musharaka in PLS financing, positively affect the real sector's output and does not effect to inflation.

Second, based on the IRF result, the whole shocks from SBI, Interbank, interest rates and credit (conventional) affect negatively and permanently the inflation and economic growth (except SBI to inflation), and indicates of speculative behavior. On the other hand, the shock of SBIS, PUAS, Islamic profit sharing and financing shows permanent and positive impact on inflation and economic growth, without indication of speculative behavior.

Third, referring to the variance decomposition result, the overall conventional variables, which are primarily financial sector variables, naturally play the role in triggering inflation and slowing the growth. An exception is for SBI (conventional), which contribute $1.52 \%$ in keeping inflation. The role of SBI in detaining inflation during monetary contraction are in accordance with conventional practice of monetary policy over the years, but fueling inflation through an increase in lending rates and lowered economic growth. On the other hand, the Islamic variables which are mainly real sector variables, naturally contributed to contain inflation and to stimulate economic growth.

These three findings lead to the empirical conclusion that monetary policy to reduce inflation with Islamic patterns is more effective than conventional patterns. These conclusions provide some logical implications, (i) in the dual monetary system, an alternative approach to 
monetary policy, can be conducted using a quantitative approach that is not contrary to the conventional and Islamic Policy Rates. This is in line with the proposed strategy of Choudhury (1997), Ascarya, etal. (2007) and Ascarya and Shakti (2008); (ii) pricing approach can still be used, but using Real Rate of Returnas a policy rate, so it can be applicable to conventional and Islamic policies. It is also in line with Ryandono (2006), Ascarya, etal. (2007), Ascarya, etal. (2008), Ascarya (2009), and Ascarya and Yumanita (2009), so that monetary policy is not only to control inflation, but also to eradicate inflation; (iii) in line with points (i) and (ii), then SBIS should use sharing profit contract (or musharakah mudharabah), rather than fee-based (ju'alah), to give better effects on macroeconomic stability and inflation reduction. 


\section{REFERENCES}

Achsani, N.A., O. Holtemöller and H. Sofyan, 2005. "Econometric and Fuzzy Modeling of Indonesian Money Demand." in: Pavel Cizek, Wolfgang H., and Rafal W. Statistical Tools For Finance and Insurance. Berlin Heidelberg, Germany: Springer-Verlag.

Alamsyah, Halim and Abdul Kadir Masyhuri. 2000. "Inflation Targeting Sebagai Kerangka Kerja Alternatif Bagi Kebijakan Moneter." "Paper. Mimeo.

Ascarya. 2007. Akad dan Produk Bank Syariah. Jakarta, Indonesia: Rajawali Pers.

Ascarya. 2008. "Menuju Sinergi Optimal Kebijakan Moneter dalam Sistem Keuangan/Perbankan Ganda." "Jurnal Ekonomi dan Bisnis Indonesia Vol.23, No.1.

Ascarya. 2009a. "Lessons Learned from Repeated Financial Crises: An Islamic Economic

Perspective." "Buletin Ekonomi Moneter dan Perbankan, Bank Indonesia, Vol.12, No.1.

Ascarya. 2009b. "The Determinants of Inflation under Dual Monetary System in Indonesia." "Working Paper, Bank Indonesia.

Ascarya. 2009c. "Toward Optimum Synergy of Monetary Policy in Dual Financial/Banking System." "Journal of Indonesian Economy and Business, Vol.24, No.1.

Ascarya. 2010. "Peran Perbankan Syariah dalamTransmisi Kebijakan Moneter Ganda di Indonesia." "Iqtisodia, Republika, August 26.

Ascarya and Ali Sakti. 2008. "Comparing Monetary Policy Instruments under Dual Financial

System: interest System vs. Profit-and-Loss Sharing System." "Journal of Islamic Business and Economics, Vol. 2, No. 1, Yogyakarta: Laboratorium Ekonomi dan Bisnis Islam.

Ascarya, Ali Sakti, Noer A. Achsani, and Diana Yumanita. 2007. "Towards INTegrated Monetary Policy under Dual Financial System: interest System vs. Profit-and-Loss Sharing System." "Working Paper, Bank Indonesia.

Ascarya and Diana Yumanita. 2009. "Formulasi Stabilitas Sistem Keuangan Ganda di Indonesia." "Working Paper, Bank Indonesia."

Ascarya, Heni Hasanah, and Noer A. Achsani. 2008." "Perilaku Permintaan Uang dalam Sistem

Moneter Ganda di Indonesia." "Buletin Ekonomi, Moneter dan Perbankan Bank Indonesia Vol. 11, No. 1. Jakarta: Bank Indonesia.

Aydin, Halil Ibrahim. 2007. "Interest Rate Pass-Through in Turkey." Central Bank of Turkey Working Paper.

'Ayuniyyah, Qurroh, Noer A. Achsani, and Ascarya. 2010. "Analisis Pengaruh Instrumen Moneter Syariah dan Konvensional terhadap Pertumbuhan Sektor Riil di Indonesia." "Iqtisodia, Republika, August 26.

Banerjee, Anindyaet al. 1998. "Error-Correction Mechanism Tests for Cointegration in a SingleEquation Framework." Journal of Time Series Analysis Vol. 19 No. 3. Blackwell Publishers Ltd. 
Best, Robin. 2008. "An Introduction to Error Correction Models." LectureNotes. Oxford Spring School for Quantitative Methods in Social Research.

Betancourt, Rocio, Hernando Vargas, and Norberto Rodriguez. 2008. "Interest Rate Pass-Through in Columbia." Cuadernos de Economia Vol.45 (Mayo) pp.29-58.

Bredin, Don, Trevor Fitzpatrick, and Gerard O Reilly. 2001. "Retail interest Rate Pass-Through: The Irish Experience." Technical Paper No.06/RT/01. Central Bank of Ireland.

Burgstaller, Johann. 2005. "Interest Rate Pass-Through Estimates from Vector Autoregressive Model." "Mimeo.

Chapra, M. Umer. 1985. Towards a Just Monetary System. Leicester, UK: The Islamic Foundation. Chapra, M. Umer. 1996. "Monetary Management in an Islamic Economy." "Islamic Economic Studies Vol. 4, No. 1.

Chapra, M. Umer. 2000. "Why has Islamic Prohibited interest?" "Review of Islamic Economics, No. 9.

Choudhury, Masudul Alam. 1997. Money in Islam: A Study in Islamic Political Economy, London, UK: Routledge.

Chionis, Dionysiosand Costas A. Leon.2006. "Interest Rate Transmission in Greece: Did EMU Cause a Structural Break?" Journal of Policy Modeling No.28 pp.453-466.

Chmielewski, Tomasz. 2004. "Interest Rate Pass-Through in the Polish Banking Sector and Banking Specific Financial Disturbances." "Mimeo. National Bank of Poland.

Crespo-Cuaresma, Jesus, Balazs Egert, and Thomas Reininger. 2004. "Interest Rate Pass-Through in New EU Member States: The Case of the Czech Republic, Hungary, and Poland." "William Davidson Institute Working Paper No.671 May.

De Bondt, Gabe. 2002. "Retail Bank interest Rate Pass-Through: New Evidence at the Euro Area Level." European Central Bank Working Paper Series No.136 April.

Direktorat Pengelolaan Moneter (DPM). 2006. Tinjauan Pelaksanaan OPT Era BI Rate dan Alternatif Penyempurnaannya." "Kajian IKU. Bank Indonesia.

Egert, Balazs, Jesus Crespo-Cuaresma and Thomas Reininger. 2006. "Interest Rate Pass-Through in Central and Eastern Europe: Reborn from Ashes Merely to Pass Away?" "William Davidson Institute Working Paper No.851 November.

Enders, Walter. 2004. Applied Econometric Time Series. $2^{\text {nd }}$ Edition. John Wiley \& Sons. USA. Espinosa-Vega, Marco A. and Alessandro Rebucci. 2003. "Retail Bank interest Rate Pass-Through:

Is Chile Atypical?" "IMF Working PaperNo.WP/03/112.

Gujarati, Damodar N. 2004. Basic Econometrics. 4 ${ }^{\text {th }}$ Edition. Mc.Graw-Hill.

Horvath, Csilla, Judit Kreko, and Anna Naszodi. 2005. "Interest Rate Pass-Through: The Case of Hungary." "Mimeo.

International Islamic University Malaysia. 2002. International Conference on Stable and Just Global Monetary System: Viability of the Islamic Gold Dinar, Proceedings, International Islamic University Malaysia, Kuala Lumpur, August 19-20.

Islahi, Abdul Azim. 1997. Konsepsi Ekonomi Ibnu Taimiyah. Binailmu. 
Karim, Adiwarman A. 2004. Sejarah Pemikiran Ekonomi Islam. Jakarta, Indonesia: Rajawali Pers.

Karim, Adiwarman A. 2007. Ekonomi Makro Islami. Jakarta, Indonesia: Rajawali Pers.

Khan, Muhammad Akram. 1999. An Introduction to Islamic Economics. KitabBhavan - New Delhi.

Keele, Luke and Suzanna De Boef. 2004. "Not Just for Cointegration: Error Correction Models with Stationary Data." "http://www.nuffield.ox.ac.uk/Politics/papers.

Kwapil, Claudia and Johann Scharler. 2006. "Interest Rate Pass-Through, Monetary Policy Rules and Macroeconomic Stability." "Oesterreichische Nationalbank Working Paper No. 18.

Kobayashi, Teruyoshi. 2008. "Incomplete Monetary Pass-Through and Optimal Monetary Policy." International Journal of Central Banking Vol.4 No.3 September.

Marotta, Giuseppe. 2007. "Structural Breaks in the Lending interest Rate Pass-Through and the Euro." Mimeo. Dipartimento di Economia Politica, Università di Modena e Reggio Emilia, and CEFIN.

Meera, Ahamed Kameel M. 2004. The Theft of Nations: Returning to Gold. Subang Jaya, Malaysia: Pelanduk Publications.

Qayyum Abdul, Sajawal Khan, andldreesKhawaja. 2005. "Interest Rate Pass-Through in Pakistan: Evidence from Transfer Function Approach." The Pakistan Development Review Vol.44 No.4 pp.975-1001.

Sakti, Ali. 2007. Sistem Ekonomi Islam: Jawaban atas Kekacauan Ekonomi Modern. Jakarta, Indonesia: Paradigma \& Aqsa Publishing.

Siddiqui, Shamin Ahmad. 2008. "An Evaluation of Research on Monetary Policy and Stability of the Islamic Economic System." "Paper. $7^{\text {th }}$ International Conference on Islamic Economics: 30 Years of Research in Islamic Economics, Jeddah: KAAU-IRTI, April.

Sorensen, ChristofferKokand Thomas Werner. 2006. "Bank interest Rate Pass-Through in the Euro Area: A Cross Country Comparison." "ECB Working Paper Series No. 580.

Sukmana, Raditya and Salina H. Kassim. 2010. "Roles of the Islamic Banks in the Monetary Transmission Process in Malaysia." International Journal of Islamic and Middle Eastern Finance and Management, Vol. 3, No. 1.

Warjiyo, Perry and Juda Agung [Eds]. 2002. Transmission Mechanisms of Monetary Policy in Indonesia. Jakarta: Bank Indonesia.

Tieman, Alexander. 2004. "Interest Rate Pass-Through in Romania and Other Central European Economies." IMF Working Paper No.WP/04/211.

Van Leuvensteijn, Michiel, ChristofferKok Sorensen, Jacob A. Bikker, and Adrian ARJM van Rixtel. 2008. "Impact of Bank Competition on the interest Rate PassThrough in the Euro Area." "ECB Working Paper Series No.885. 